\title{
Catecholamine-Storing Cells in the Cyclostome Heart
}

\author{
Nagayasu Otsuka, Jun Chinara, Hiromi Sakurada \\ and \\ Shigeto KANDA
}

\begin{abstract}
Summary. The lamprey heart contains characteristic catecholamine-storing cells in both the atrium and the ventricle. Sufficient circumstantial evidence is avaiable indicating that catecholamines together with protein carbohydrate complexes are contained in these cells within the membrane bound cytoplasmic granules. If the "recepto-secretory function" and "neuroectodermal origin" of these cells are proved, then they may be classified as typical paraneurons.
\end{abstract}

Using a fluorescence histochemical method for monoamines (FALCK-HillarP), numerous green to yellow green fluorescent cells were demonstrated in both the atrium and the ventricle of the lamprey heart. Judging from the fluorescence color, monoamines contained in these cells are not indolamines but are catecholamines; hence, we call these specific cells catecholamine-storing cells (DAHL et al., 1966; Окамото et al., 1970, Отsuka et al., 1974).

These catecholamine-storing cells are seen in the endocardium, in the myocardium between the heart muscle cells, and in the pericardium. They are embedded in the heart tissue such that they do not open to either the pericardial cavity or the cardiac lumen (Fig. 1).

The catecholamine-storing cells in the lamprey heart are variable in size $(8-20 \mu \mathrm{m}$ in diameter) and contain a large nucleus with prominent nucleoli. They frequently take the form of bipolar or multipolar cells (TRETJAKOFF, 1927). Branches of cytoplasmic protrusions from the catecholamine-storing cells frequently lie between the heart muscle cells (BLoom et al., 1961; Otsuka et al., 1974).

The catecholamine-storing cells in the lamprey heart cannot be identified in conventional haematoxylin-eosin stained sections. But, by using the silver impregnation method (BLoom et al., 1961), it is possible to demonstrate the cell outline (Fig. 2). The cells give a positive chromaffin reaction and stain a bluish tone by the chrome haematoxylin of Gomori (BLoom et al., 1961).

In electron microscopy, the catecholamine-storing cells have an outline varying from an elongated shape to a rather irregular shape having branching cytoplasmic processes running among the neighboring heart muscle cells. The catecholaminestoring cells contain many dense-cored vesicles in the cytoplasm (Fig. 3). These granules are mostly sphrical in shape, 0.15 to $0.3 \mu \mathrm{m}$ in diameter, and are bound by a limiting membrane. A thin halo is present between the electron-dense core and the limiting membrane. Biochemical studies showed that these granules contain large amounts of catecholamines (Augstinsson et al., 1956; Bloom et al., 1961). Cytoplasmic structures including a Golgi complex, granular endoplasmic reticulum, mitochondria and lysosomes are distributed in the paranuclear cytoplasm (ÖstLund et al., 1960; Bцоом et al., 1961; Oтsuka et al., 1969). 
After reserpine administration, the catecholamine-content of the catecholaminestoring cells rapidly decreases (Окамото et al., 1970). Reserpine administration also induces a conspicuous decrease in the number of membrane-bound granules in the catecholamine-storing cells. However, no signs of granule degeneration are seen in the catecholamine-storing cells.

After administration of L-dopa, both fluorescence intensity and the number of catecholamine-storing cells increase (Окамото et al., 1970). An increase in number of the membrane-bound granles is also demonstrable (Окамото et al., 1970).

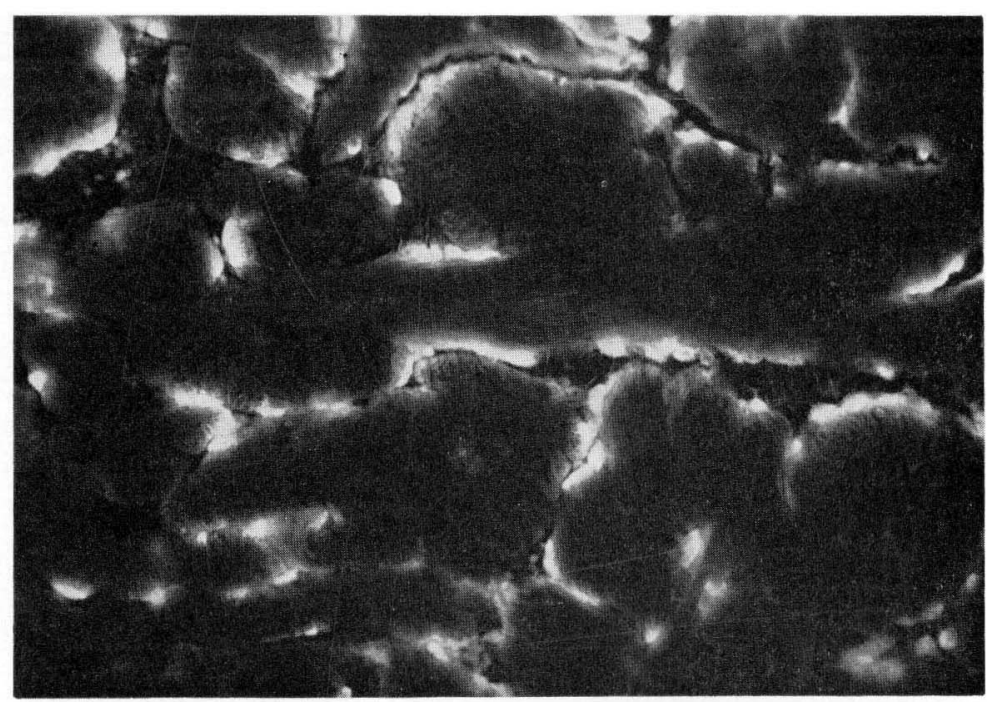

Fig. 1. Catecholamine-storing cells of the atrium in the L-dopa treated lamprey. Falck-Hillarp method. $\times 300$

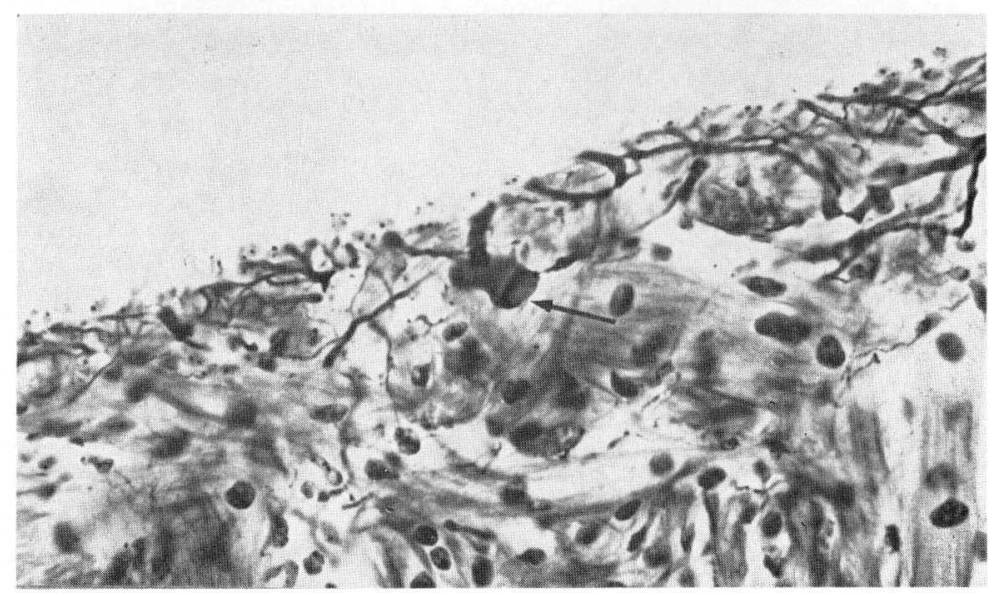

Fig. 2. Light microscopical pictures of catecholamine-storing cells of the lamprey atrium. Cell body (arrow) and branching cytoplasmic processes are seen. Bodian-Otsuka silver staining method. $\times 380$ 


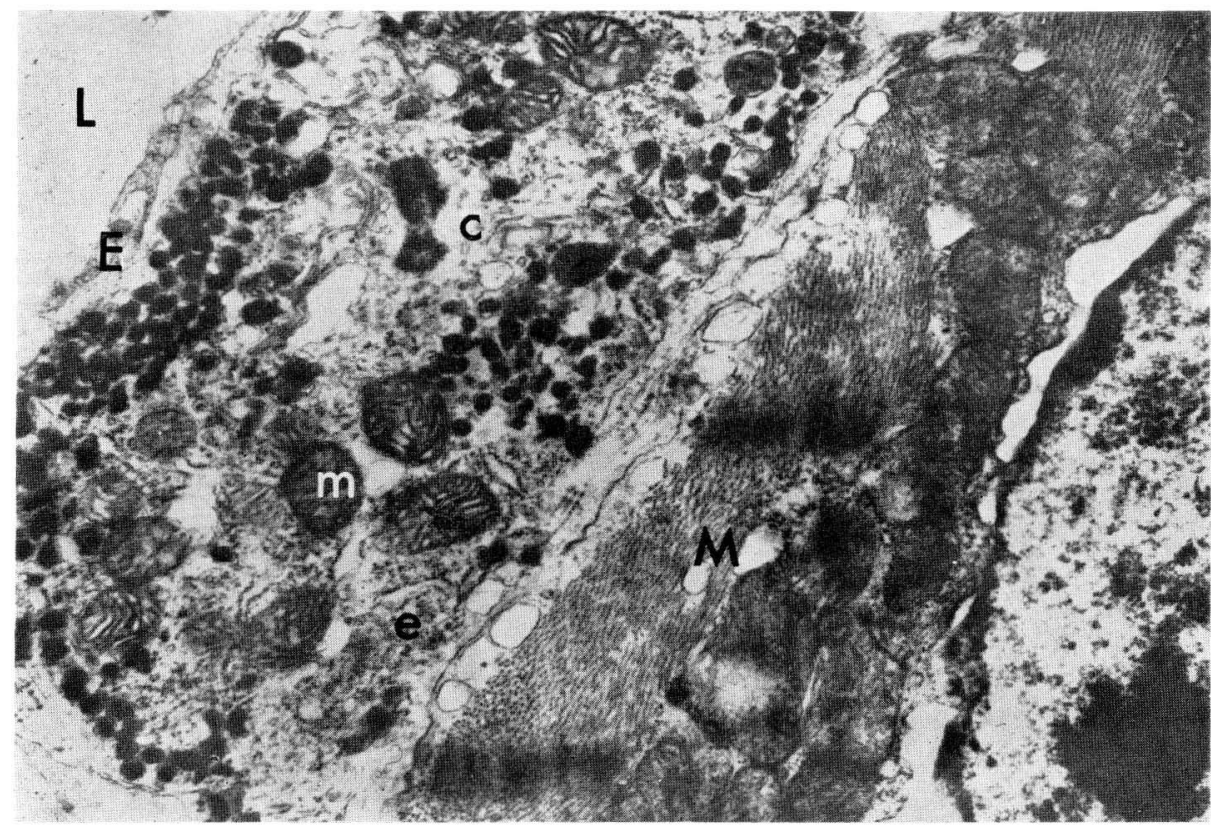

Fig. 3. Electron micrograph of a catecholamine-storing cell $(c)$ in reserpine-treated lamprey atrium. It contains many membrane-bound dense granules, mitochondria $(m)$ and granular endoplasmic reticulum $(e) . \quad L$ cardiac lumen, $E$ endothelial cell, $M$ cardiac muscle cell. $\quad \times 12,000$

FujiTa cited the following four criteria for paraneuron classification: (1) the production of neurotransmitters; (2) the possession of synaptic-like and/or neurosecretionlike granules; (3) the recepto-secretory function; and (4) the neuroectodermal origin (for details, see Fujit A, 1976). As briefly mentioned in the present paper, the catecholamine-storing cells of the lamprey heart satisfy the first and second criteria for classification as a paraneuron. These cells possess membrane-bound cytoplasmic granules containing catecholamines and protein carbohydrate complexes (Shibata and Үлмамото, 1976). However, in order to decide whether they belong to the paraneurons, further studies are needed in regard to the receptosecretory function and neuroectodermal origin. The observation that the catecholamine-storing cells in the lamprey heart have no synaptic contacts with nerve fibers (OTSUKA, unpublished) could be an important factor in future studies.

ヤツメウナギの心臓にみられるカテコールアミン含有細胞

$$
\begin{aligned}
& \text { 大塚長康, 千原純 } \\
& \text { 桜 田寞 海, 荻田成人 }
\end{aligned}
$$

ヤッメウナギの心臟にみられるカテコールアミン含有細胞に関する 螢光法,ならびに電 子顕微鏡によるこれまでの研究成果を概観した。

この細胞はヤッメウナギの心臟の心内膜下，心外膜下，心筋層内に存在し，FALCK- 
HILLARP による螢光法で その細胞体と突起が強い黄緑色の蛍光を呈した. また，レセル ピンの投与により螢光は減退 または消失し， Lードパ投与により増強された。

電子顕微鏡による観察により，この細胞には 直径 0. 15-0.3 $\mu \mathrm{m}$ の電子密度の高い果粒 が多数存在し，この果粒はレセルピン投与で減少し，Lードパ投与で増加した。 また，この 果粒性化学的な分析や電顕的組織化学から カテニールアミンを含んでいることが明ら かにされた。 この細胞の機能に関してパラニューロンとの関係が討論された。

\section{References}

Augustinsson, K. B., R. Fänge, A. Johnels and E. Östlund : Histological, physiological and biochemical studies on the heart of two cyclostomes, hagfish (Myxine) and lamprey (Lampetra). J. Physiol. 131: 257-276 (1956).

Bloom, G., E. Östlund, U. S. von Euler, F. Lishajko, M. Ritzén and J. Adams-Ray : Studies on catecholamine-containing granules of specific cells in cyclostome heart. Acta physiol. scand. 53, suppl. 185: 1-34 (1961).

Dahl, E., B. Falck, C. V. Mecklenburg, H. Myhrberg and E. Rosengren : On the monoamine storing cells in the hearts of Lampetra fluviatilis and L. planeri. (cited from FALCK et al., 1966).

Falck, B., C. Von Mecklenburg, H. Myhrberg and H. Persson : Studies on adrenergic and cholinergic receptore in the isolated hearts of Lampetra fluviatilis (cyclostomata) and Pleuronectes platessa (teleostei). Acta physiol. scand. 68: 64-71 (1966).

Fujita, T.: The gastro-enteric endocrine cell and its paraneuronic nature. In: (ed. by) R. E. Coupland and T. Fujita: Chromaffin, enterochromaffin and related cells. Elsevier, Amsterdam, 1976. (p. 204-208).

Okamoto, H., N. Otsuka and T. Matsuura: The fine structure of cyclostome cardiac muscle cells (II). J. Electron Microsc 19: 315 (1970).

Östlund, E., G. Bloom, J. Adams-Ray, F. Lishajko and U. S. von Euler: Strage and release of catecholamine and the occurrence of specific submicroscopic granulation in hearts of catecholamines. Nature 188: 324-325 (1960).

Otsuka, N., T. Isobe, K. Inoue, T. Nishi and M. Tomisawa : Observation on monoaminergic innervation of vertebrata heart. Auton. Nerv. System 11: 95-103 (1974).

Otsuka, N., M. Tomisawa and H. Okamoto: The fine structure of cyclostom cardiac muscle cells. J. Electron Microsc. 18: 221 (1969).

Shibata, Y. and T. Yamamoto: Fine structure and cytochemistry of specific granules in the lamprey atrium. Cell Tiss. Res. 172: 487-501 (1976).

Tretjakoff, D.: Das periphere Nervensystem des Flußneunauges. Z. wiss. Zool. 129: 359-452 (1927).

大塚長康

₹700 岡山市鹿田町 2-5-1

岡山大学医学部

解剖学教室第一講座
Prof. Nagayasu OTsuka

Department of Anatomy

Okayama University School of Medicine

Okayame, 700 Japan 